Warszawskie Studia Pastoralne UKSW

Rok XI 2016 Nr 3 (32)

Ks. Marek Filipczuk

(Uniwersytet Kardynała Stefana Wyszyńskiego - Warszawa)

\title{
CHRYSTUS - PRAWDA - SUMIENIE. TRZY FILARY CHRZEŚCIJAŃSKIEGO WYCHOWANIA MORALNEGO
}

Christ - Truth - Conscience. Three Pillars of Christian Moral Education

W obliczu wielu zagrożeń moralnych współczesności Kościół, który jest znawcą spraw ludzkich, podkreśla konieczność formacji sumienia. Postulat ten znajduje się nie tylko w oficjalnych wypowiedziach Urzędu Nauczycielskiego, ale także w refleksji teologiczno-katechetycznej wielu uczonych katolickich. Ten wymiar misji Kościoła wydaje się szczególnie ważny w kontekście Starego Kontynentu, którego głównym problemem jest głęboko zdeformowane ludzkie wnętrze: zachwiana prawidłowa relacja wolności człowieka do prawdy. Stąd też konieczność uczynienia na powrót prawymi pokrzywionych ludzkich sumień staje przed Kościołem XXI wieku jako zadanie pierwszorzędnej wagi. Ażeby wychowywać człowieka na obywatela Europy jutra, na budowniczego Europy jako wspólnego domu dla wszystkich mieszkańców, trzeba zaczać od pracy nad sumienieml.

Zagadnienie ukazania podstawowego znaczenia prawdy w życiu zarówno poszczególnych osób, jak i całych społeczeństw wydaje się być szczególnie aktualne we współczesnej kulturze demokratycznej, w której rozpowszechnił się pogląd, że porządek prawny społeczeństwa powinien być zbudowany wyłącznie na tym, co większość obywateli stosuje i uznaje za moralne. Od 1989 roku Kościół w Polsce zaczął wpisywać się w nowe demokratyczne formy życia społecznego,

1 T. Styczeń, Sumienie a Europa czyli Gdyby Ojciec Święty zaprosił Arystotelesa na Synod Biskupów Europy 1991, „Ethos” 1991, nr 15-16, s. 162-163. 
co nie pozostaje bez konsekwencji dla moralności Polaków. Pośród tych form jedną z bardziej niebezpiecznych, bo prowadzących w prostej linii do relatywizu moralnego i deformujących działanie sumienia, jest kryterium kompromisu, tzn. stosowanie zasady łatwizny, powszechnej konwencji, płynięcia z prądem, uległości wobec aktualnej mody itp.

Aktualność tematu podyktowana jest także typowym obecnie zagrożeniem w dziedzinie wychowania ku wartościom: traktowania dobrego nastroju emocjonalnego jako istotnej wartości i podstawowego kryterium postępowania. Szuka się więc dla siebie religii stosownej, wygodnej, odpowiadającej duchowi konsumpcjonizmu, tzn. takiej, która dawałaby człowiekowi komfort poczucia bezpieczeństwa w zaświatach, która pełniłaby funkcję terapeutyczną, podejmowałaby wszechstronną działalność charytatywną oraz dawałaby określone przeżycia uczuciowe.

\section{Istota $\mathrm{i}$ miejsce formacji sumienia $\mathrm{w}$ wychowaniu moralnym}

Wychowanie moralne nie jest jednym $\mathrm{z}$ równorzędnych rodzajów czy działów wychowania, ani nie jest jakąś odrębną dyscypliną, której można by się wyuczyć. Łączy się ono konstytutywnie z globalnym (całościowym) wychowaniem osoby i z tego kontekstu nie może być wyizolowane. Wychowanie moralne stanowi cel sam w sobie: zamierza wprowadzić katechizowanego w świat, gdzie zawsze jest miejsce na nawrócenie oraz doskonalenie istniejącego porządku. Według J. Ratzingera wychowanie moralne jest wprowadzeniem w etos i konfrontacją etosu z etyką ${ }^{2}$. A człowiek potrzebuje etosu, by być sobą. Tam bowiem, gdzie nie ma już nic, za co warto by było umrzeć, tam nie warto również $i \dot{z} y c ́$; $\dot{z} y c i e$ utraciło swoje "po co"

2 Por. S. Kunowski, Wychowanie moralne jako istotny element wychowania chrześcijańskiego, w: Wychowanie w rodzinie chrześcijańskiej, red. F. Adamski, Kraków 1982, s. 94; C. Rogowski, Wychowanie moralne dzisiaj, „Katecheta” 1996, nr 4, s. 205-206; J. Szpet, Dydaktyka katechezy, Poznań 1999, s. 84.

3 J. Ratzinger, Czas przemian w Europie, Kraków 2001, s. 33-34. 
Wychowanie religijne zawiera w sobie wychowanie moralne, które w nim właśnie znajduje swoje ostateczne ukoronowanie ${ }^{4}$. Z kolei wychowanie moralne - na co wskazują dokumenty ostatnich pontyfikatów - powinno być przede wszystkim formacją sumienia ${ }^{5}$. Ponieważ sama wiedza o tym, co dobre i co złe nie wystarczy, niezmiernie ważnym w wychowaniu moralnym okazuje się jasne pojęcie sumienia, słuchanie głosu tego żywego świadka, adwokata i sędziego, pielęgnowanie i kształtowanie moralnej władzy sądzenia. Środowiskiem wychowawczym, w którym w głównej mierze nabywa się tej umiejętności, jest rodzina. Pierwszym bowiem z zadań rodziny jest kształtowanie sumienia ${ }^{6}$. Można zatem powiedzieć, że katecheza rodzinna zakłada mocny fundament świadectwa rodzinnej miłości pod proces wychowania moralnego. Człowiek, jeśli chce dojść do osobowej doskonałości, nie zrealizuje jej inaczej, jak tylko przez realną miłość ku drugiemu człowiekowi; nie może bowiem żyć bez miłości ${ }^{7}$. Wobec powyższego przykazanie miłości jawi się jako podstawowa norma dla formacji moralnej.

Formację sumienia można w jakimś sensie utożsamiać $\mathrm{z}$ wychowaniem moralnym, ale również, $\mathrm{z}$ drugiej strony, każdy proces wychowania jest w swoim jądrze procesem wychowania sumienia. Konieczność katechezy o sumieniu jest tym bardziej paląca, że wstrząsy, jakim podlega dzisiejsza kultura, nieustannie wystawiają sumienie człowieka na próbę. W takiej sytuacji zadaniem niezmiernie istotnym wydaje się ukształtowanie prawidłowego sumienia, a następnie pobudzanie go

${ }^{4}$ Por. J. Charytański, Wychowanie moralne w katechezie, w: Podręcznik metodyczny do Katechizmu religii katolickiej, red. J. Charytański, W. Kubik, cz. 4, Warszawa 1980, s. 21-23; W. Gubała, Wychowanie moralne młodzieży, w: Teoretyczne założenia katechezy młodzieżowej, red. R. Murawski, Warszawa 1989, s. 211.

5 Por. PMW 2, s. 12; PDK 26.

6 Por. VS 64; R. Schnackenburg, Nauka moralna Nowego Testamentu, Warszawa 1983, s. 256; J. Szpet, Wychowanie do pokuty w rodzinie i w katechezie parafialnej, w: Pokuta i sakrament pojednania we współczesnym Kościele, Poznań 1985, s. 49. Zob. CT 68; LR 16; DOK 225.

7 RH 10. Por. M. A. Krąpiec, Człowiek i prawo naturalne, Lublin 1986, s. 163. Zob. także Benedykt XVI, Deus caritas est, Watykan 2005, nr 16-17. 
do oceny wartości moralnych celem osobistego wyboru ich i przyjęcia za własne ${ }^{8}$.

Wychowywanie człowieka w duchu pedagogiki chrześcijańskiej oznacza pomaganie mu wchodzić w relację osobową z Bogiem, która ma miejsce szczególnie w akcie sumienia. Oznacza to jednocześnie wychowywać w nim autentyczne sumienie moralne i wprowadzać w krąg przeżyć i doznań religijnych, czyniąc go dyspozycyjnym na apel Boga' ${ }^{9}$ Prawdziwa odnowa człowieka i społeczeństwa dokonuje się zawsze za sprawą odnowy sumien' ${ }^{10}$. Ostatecznie więc wychowawcza troska o człowieka to przede wszystkim troska o uformowanie jego sumienia, o to, by poznał prawdę i dobro, i by w swoim życiu postępował zgodnie z poznaną prawdą, albowiem chrześcijaństwo godne swego miana nie może się wyrażać jedynie w przeciętnej uczciwości, dostosowanej do norm społecznych, ale musi być prawdziwym dążeniem do świętości $i^{11}$.

Formacja moralna nie tylko przekazuje treść moralności chrześcijańskiej, lecz również czynnie kultywuje postawy ewangeliczne i wartości chrześcijańskie. W wychowaniu moralnym nie chodzi bowiem jedynie o znajomość pojęć, ale o postawę katechizowanego wyrażającą się w dążeniu do osiągnięcia nowego sposobu bytowania w Chrystusie (esse in Christo) ${ }^{12}$. Następstwem tego nowego istnienia

8 Por. W. Kawecki, Spowiedź a kształtowanie sumienia, „Homo Dei” 2001, nr 1, s. 42; R. Guardini, Zjawisko sumienia, „Znak” 1996, nr 7, s. 24; ReP 26; S. Kunowski, Wychowanie moralne jako istotny element wychowania chrześcijańskiego, art. cyt., s. 87.

9 Por. M. Nowak, „Sumienie” jako szczególne miejsce doświadczania i urzeczywistniania swojego człowieczeństwa, w: Sumienie. Głos Boga w duszy. Wybór tekstów, opr. M. Czekański, Kraków 2002, s. 182-183.

10 Por. Jan Paweł II, Odnowa człowieka i społeczeństwa dokonuje się za sprawa odnowy sumień (14 II 1998), 2, „L’Osservatore Romano” - wydanie polskie 1998, nr 3. Zob. także Franciszek, Modlitwa na Anioł Pański 6 grudnia 2015, http://papiez. wiara.pl/doc/2862422.Franciszek-o-potrzebie-ciaglego-nawrocenia.

11 Jan Paweł II, List do kapłanów na Wielki Czwartek (25 III 2001), 15.

12 J. Szpet, Dydaktyka katechezy, dz. cyt., s. 84. 
musi być nowy sposób działania ${ }^{13}$. A żyć z Boga znaczy: nie realizować siebie, nie chcieć samemu brać świata $w$ ręce, pożegnać się $z$ marzeniami o samowystarczalności i autonomii, jakbyśmy byli w stanie sami działać, uczyć się naprawdę przyjmowania życia dzień po dniu z Jego ręki, ufnie i bez strachu ${ }^{14}$. Taki jest zresztą cel katechezy moralnej, która wyrażając w sposób bardzo jasny radość i wymagania drogi Chrystusa, winna stać się katechezą nowego życia w Chrystusie. Koniecznym i bezpośrednim następstwem tej egzystencjalnej sytuacji wierzącego człowieka jest więc to, że musi się on przyoblec w Chrystusa i walczyć ze złem, umarwiając i zapierając się samego siebie ${ }^{15}$.

Celem działania sumienia - w perspektywie teologicznej - jest doprowadzenie do sytuacji, w której człowiek będzie słuchał głosu Chrystusa żyjącego w nim. A Chrystus najpierw obdarowuje nowym życiem, a dopiero potem wzywa do tego, by żyć na miarę tego daru. Dlatego właśnie kształtowanie sumienia oznacza zarazem kształtowanie dojrzałych postaw ludzkich i chrześcijańskich. Jest to problem tym bardziej palący w obecnej sytuacji, w której epokę współczesną znamionuje pomieszanie pojęć i chaos poglądów ${ }^{16}$.

\section{Wychowanie sumienia - prawo i obowiązek chrześcijanina}

Sumienie ludzkie, jako zdolność poznania i wartościowania moralnego, nie tylko może, ale również powinno być formowane i kształtowane ${ }^{17}$. Sumienia nie można pozostawić samemu sobie, bez żadnej

\footnotetext{
13 Por. Jan Paweł II, Podstawa etyki chrześcijańskiej: związek pomiędzy prawda i wolnością (13 VI 1983), 1, „L'Osservatore Romano” - wydanie polskie 1983, nr 7-8.

14 J. Ratzinger, Granice dialogu, Kraków 1999, s. 91.

15 Por. CT 29; KKK 1697; Jan Paweł II, Chrystus jest cała prawda człowieka (31 VIII 1983), 3, „L'Osservatore Romano” - wydanie polskie 1983, nr 7-8.

16 Por. R. Jaworski, Seminarium miejscem dojrzewania sumienia, „Pastores” 1999, nr 3, s. 49; J. Nagórny, Z Chrystusem w Trzecie Tysiąclecie, w: Wyzwania moralne przełomu tysiącleci, red. J. Nagórny, A. Derdziuk, Lublin 1999, s. 165; S. Kunowski, Wychowanie moralne jako istotny element wychowania chrześcijańskiego, art. cyt., s. 88.

17 Por. J. Bagrowicz, Wychowanie sumienia u podstaw wychowania integralnego, w: Edukacja wobec dylematów moralnych współczesności, red. F. Adamski, A. M. de Tchorzewski, Kraków 1999, s. 88.
} 
opieki ${ }^{18}$. Współczesny człowiek zafascynowany jest wolnością. Można powiedzieć, że jest chory na wolność ${ }^{19}$. W naszym stuleciu, jak w żadnym innym okresie historii, wolność odsłoniła swoją moc destrukcji ${ }^{20}$. Jan Paweł II zauważa, że w niektórych nurtach myśli współczesnej do tego stopnia podkreśla się znaczenie wolności, że czyni się z niej absolut, który ma być źródłem wartości $i^{21}$. Jednak wywalczona w taki sposób wolność pozostaje pusta. Owszem, jesteśmy zobowiązani do wolności, nie tylko dlatego, że jest ona zarówno prawem, jak i obowiązkiem człowieka, ale także ze względu na nasz cel ostateczny i nakaz doskonalenia osobowego ${ }^{22}$. Tymczasem zapomina się niejednokrotnie, że wolność nie jest naturalnym przymiotem ludzkości ani nie usprawiedliwia się sama przez się. Zdobycie wolności połączonej z odpowiedzialnością jest zadaniem, które musi podjąć każdy człowiek ${ }^{23}$.

Dla każdego chrześcijanina kształtowanie sumienia jest zarówno podstawowym prawem, jak i podstawowym zadaniem nie tylko do realizowania na pewnym etapie ludzkiego życia. Jest to raczej powinność spoczywająca na chrześcijaninie przez całe jego życie, ponieważ proces wychowania nigdy się nie kończy ${ }^{24}$. Jak pisze Jan Paweł II: każdy chrześcijanin powinien być człowiekiem sumienia odnoszacym naprzód to najważniejsze i poniekąd najtrudniejsze ze

\footnotetext{
18 K. Romaniuk, Jak żyć i po co?, Częstochowa 1996, s. 99.

19 Por. S. Rosik, Sumienie między wolnościa a prawdą, w: Człowiek sumienie, wartości, red. J. Nagórny, A. Derdziuk, Lublin 1997, s. 108.

20 Por. J. Kupczyk, W stronę wolności. Szkice o antropologii Karola Wojtyły, Kraków 1999, s. 97.

21 VS 32.

22 Por. J. Ratzinger, Prawda, wartości, władza, Kraków 1999, s. 58; J. Majka, Chrześcijańska myśl społeczna, Warszawa 1982, t. 3, s 124.

${ }^{23}$ Por. Jan Paweł II, Podróż apostolska Jana Pawła II na Kubę - Hawana, Msza św. na pl. Rewolucji im. José Martí (23 I 1998), Ewangelia jest droga pokoju, sprawiedliwości i wolności, 6, „L'Osservatore Romano” - wydanie polskie 1998, nr 3; R. J. Neuhaus, Biznes i Ewangelia, Poznań 1993, s. 25.

24 Por. M. Napieralski, O nowym katechizmie, Warszawa 1994, s. 106; KKK 1784; J. Rozwadowski, Integralny związek czynnika nadprzyrodzonego i naturalnego $w$ wychowaniu chrześcijańskim, w: Wychowanie w rodzinie chrześcijańskiej, red. F. Adamski, Kraków 1982, s. 56.
} 
zwycięstw - zwycięstwo nad samym sob $a^{25}$. Człowiek wierzący ma obowiązek ustawicznie urabiać, kształcić, formować własne sumienie, odwołując się przy tym nie do czysto subiektywnych odczuć, lecz do kryteriów obiektywnych, a takimi są prawdy przez Boga objawione i przez Kościół podane do wierzenia. Nie ma bowiem takiego punktu osiągalnego ludzkim wysiłkiem, po przekroczeniu którego wolno byłoby cieszyć się zdobytym stanem doskonałości. Moralność wypływająca $z$ wiary jest moralnością dynamiczną, która nigdy nie pozwala chrześcijaninowi zaprzestać wysiłku i być zadowolonym $\mathrm{z}$ siebie ${ }^{26}$.

Wychowanie i ustrzeżenie przez całe życie prawego sumienia wiąże się ze stawianiem sobie wymagań, by postępować w sposób szlachetny i zgodny z głosem sumienia ${ }^{27}$. Być człowiekiem sumienia to znaczy wymagać od siebie, podnosić się z własnych upadków, ciagle na nowo się nawracać ${ }^{28}$. Wychowywać sumienie, to znaczy zaprawiać rozum, aby umiał rozpoznawać prawdę moralnych sytuacji. Dojrzałość sumienia osiąga się przez wytrwałe kształtowanie w sobie umiłowania prawdy i dobra, przez urabianie woli, przez pilną dbałość o swój rozwój duchowy, o zdobywanie głębokiej mądrości w bliskiej więzi ze wszystkim, co może te wartości zagwarantować ${ }^{29}$.

\section{Chrystus - osobowa Prawda}

Pierwszym i najważniejszym twierdzeniem chrześcijańskiej nauki moralnej jest to, że Bóg w Jezusie Chrystusie objawił się jako osobowa Prawda $^{30}$. Została ona obwieszczona raz na zawsze w tajemnicy Jezusa

\footnotetext{
25 Jan Paweł II, Odnowa człowieka i społeczeństwa dokonuje się za sprawą odnowy sumień, dok. cyt., 2.

26 Por. P. Góralczyk, Sumienie a prawda i wolność, „Communio” 2000, nr 1, s. 99. Zob. także Benedykt XVI, Deus caritas est, dz. cyt., nr 28.

27 Por. M. Dziewiecki, Człowiek w obliczu sumienia, w: Sumienie. Głos Boga w duszy. Wybór tekstów, opr. M. Czekański, Kraków 2002, s. 166.

28 Jan Paweł II, Czas próby polskich sumień trwa. Homilia wygłoszona $22 \mathrm{~V} 1995$ r. w Skoczowie, 3, „Więź” 1995, nr 7.

29 Por. T. Sikorski, Sumienie, w: Słownik teologiczny, dz. cyt., s. 557.

30 Por. M. Pokrywka, Rola Duch Świętego w kształtowaniu dojrzałego sumienia, w: Sumienie. Głos Boga w duszy. Wybór tekstów, opr. M. Czekański, Kraków 2002, s. 205.
} 
z Nazaretu ${ }^{31}$. Chrystus poznawany przez chrześcijanina z osobistej, egzystencjalnej lektury Ewangelii jest całą prawdą człowieka, a co za tym idzie, jest prawem życia ludzkiego ${ }^{32}$. Należy (...) mocno uwierzyć $w$ to, że w tajemnicy Jezusa Chrystusa, wcielonego Syna Bożego, który jest droga, prawda i życiem (J 14,6), zawarte jest objawienie pełni Bożej prawdy ${ }^{33}$. Rozpoznanie i przyjęcie całej prawdy nie dokonuje się tylko w wymiarach intelektualnych, ale nade wszystko chodzi tu o przylgnięcie do Osoby samego Jezusa, uczestnictwo w Jego życiu i przeznaczeniu, udzial w Jego dobrowolnym i pełnym miłości posłuszeństwie woli Ojca ${ }^{34}$. To zbliżanie się do Boga, który jest Prawdą, umożliwia coraz pełniejszą realizację wolności człowieka. Wolność nie oparta na prawdzie oddziałuje na człowieka w taki sposób, że staje się przedmiotem, a tym samym nie ma żadnej możliwości osobistego rozwoju ${ }^{35}$.

Chrystus jako prawda znaczy: Bóg, który z niewiedzących sług zamienia nas w przyjaciół, dopuszczajac nas do współwiedzy o sobie samym ${ }^{36}$. On to poprzez wewnętrzny związek z sobą umożliwił człowiekowi znalezienie ostatecznej prawdy i swojej rzeczywistej wolności. A zatem Chrystus, Odkupiciel człowieka, czyni go wolnym ${ }^{37}$. W Chrystusie objawia się nie tylko prawda dotycząca oblicza Boga jako Ojca, a przez to i pełna prawda odnośnie do Jego woli zbawczej, lecz także prawda o człowieku ${ }^{38}$. Ta objawia się w pełni w momencie,

\footnotetext{
31 Por. FR 11; KO 2.

32 Por. A. Siemieniewski, Coraz bardziej istniejąc, upodabniamy się do Jego obrazu, w: W prawdzie ku wolności. W kręgu encykliki „Veritatis splendor”, dz. cyt., s. 235; Jan Paweł II, Chrystus jest cała prawdą człowieka, dok. cyt., 2. Zob. także DWR 14. 33 DI 5.

34 VS 19; por. M. Pokrywka, Rola Duch Świętego w kształtowaniu dojrzałego sumienia, art. cyt., s. 205.

35 Por. Jan Paweł II, Ewangelia jest droga pokoju, sprawiedliwości i wolności, dok. cyt., 6 .

36 J. Ratzinger, Nowa pieśń dla Pana, Kraków 1999, s. 38.

37 Por. DonV 3; Jan Paweł II, Orędzie na Światowy Dzień Pokoju (8 XII 1980), Chcesz służyć sprawie pokoju - szanuj wolność, 11, „L'Osservatore Romano” - wydanie polskie 1980, nr 11.

38 Por. L. Melina, Sumienie - wolność - Magisterium, „Ethos” 1991, nr. 3-4, s. 107.
} 
gdy Bóg objawia samego siebie ${ }^{39}$. Tajemnica człowieka objawia sie do końca tylko w Jezusie Chrystusie ${ }^{40}$. On objawia w pełni człowieka samemu człowiekowi ${ }^{41}$. Stało się tak za sprawą aktu Odkupienia, który wszczepił osobę ludzką w Chrystusa, czyniąc ją uczestnikiem boskiego Synostwa Słowa, dzięki czemu sumienie chrześcijańskie jest poznawaniem $z$ Chrystusem uczestnictwem przez wiarę w Jego poznaniu, które zbawia i czyni wolnymi ${ }^{42}$. Wiara jest bowiem podarowanym nam nowym sposobem myślenia i poznania ${ }^{43}$. Przez akt Odkupienia Chrystus staje się dla sumienia jedyną księgą moralności ${ }^{44}$. Odtąd wiara i postepowanie moralne stanowią jedność ${ }^{45}$. Dramat Odkupienia jawi się w tym kontekście jako dramat Boga spieszącego na ratunek uwikłanemu w niewolę nieprawdy człowiekowi ${ }^{46}$. Pokora Boga staje się drzwiami prawdy na świat; i nie ma innych - jak pisze J. Ratzinger. Ubóstwo zaś jest prawdziwie boską formą objawienia się prawdy: $\mathrm{w}$ ten sposób może ona wymagać posłuszeństwa bez wyobcowania ${ }^{47}$.

Wolność, z której wyeliminowano prawdę, jest kłamstwem ${ }^{48}$. Prawda bowiem jest granicą wolności i poza tą granicą kończy się

\footnotetext{
39 Por. R. Otowicz, „Veritatis splendor” w świetle Katechizmu Kościoła Katolickiego, $\mathrm{w}$ : W prawdzie ku wolności. W kręgu encykliki „Veritatis splendor”, red. E. Janiak, Wrocław 1994, s. 229.

40 KDK 22.

41 RH 10.

42 Por. Jan Paweł II, Chrystus jest cała prawda człowieka, dok. cyt., 1; L. Melina, Sumienie - wolność - Magisterium, art. cyt., s. 107.

43 Por. J. Ratzinger, Prawda w teologii, Kraków 2001, s. 63; J. Nagórny, Teologia moralna jako eklezjalna nauka wiary w świetle „Veritatis splendor”, w: W prawdzie ku wolności. W kręgu encykliki „Veritatis splendor”, red. E. Janiak, Wrocław 1994, s. 187.

${ }^{44}$ Por. S. Rosik, Sumienie między wolnościa a prawda, art. cyt., s. 116.

45 Por. Jan Paweł II, Szczęście osiąga się przez ofiarę, dok. cyt., 3.

46 Por. J. Marecki, T. Styczeń, „Veritatis splendor” - encyklika o wolności, w: W prawdzie ku wolności. W kręgu encykliki „Veritatis splendor”, red. E. Janiak, Wrocław 1994, s. 211.

47 Por. J. Ratzinger, Nowa pieśń dla Pana, dz. cyt., s. 45-46; por. także tenże, Granice dialogu, dz. cyt., s. 123.

48 Por. tenże, Nowa pieśń dla Pana, dz. cyt., s. 38.
} 
wolność, a rozpoczyna destruktywna samowola ${ }^{49}$. Dlatego zerwanie więzi wolności z prawdą, dzięki której osoba staje się bardziej sobą, stawia pod znakiem zapytania sensowność dramatu Odkupienia. Etos Odkupienia to spotkanie w człowieku prawdy i wolności $i^{50}$. Boska przyjaźń względem ludzi polega na tym, że Bóg wprowadził nas w sferę zaufania, a przestrzenią zaufania jest prawda ${ }^{51}$. Chrystus uczynił wszystko, ażeby przekonać nas o znaczeniu tej odpowiedzi, której człowiek powinien udzielić w warunkach wewnetrznej wolności, żeby zajaśniał w niej ów „veritatis splendor”, który jest tak zasadniczy dla godności człowieka ${ }^{52}$.

Człowiek jest zasadniczo zdolny dotrzeć do prawdy. Nie podejmowałby poszukiwania czegoś, o czym nic by nie wiedział i co uważałby za absolutnie nieosiągalne ${ }^{53}$. Zaufanie i zdolność dochodzenia rozumu do prawdy przypomina elementarne założenia, że oprócz wolności, drugą podstawową komponentą człowieka jest prawda. Aby wybrać jakąś wartość, trzeba ja najpierw poznać. Poznanie, a więc i prawda, idą przed decyzją o wyborze, przed uruchomieniem wolności ${ }^{54}$. Człowiek staje się świadkiem prawdy w wyniku poznania. Równocześnie człowiek - właśnie w związku z właściwa sobie potencjalnościa poznawcza - jest wolny ${ }^{55}$. Oznacza to w praktyce prymat poznania, zwłaszcza wspartego wiarą, nad działaniem. Oznacza to także pokorę umysłu wobec prawdy, którą można co najwyżej odkrywać, a nigdy tworzyćs ${ }^{56}$.

\footnotetext{
49 Por. S. Rosik, Sumienie między wolnością a prawdą, art. cyt., s. 114.

50 Jan Paweł II, Podstawa etyki chrześcijańskiej: związek pomiędzy prawda i wolnością, dok. cyt., 3 .

51 Por. J. Ratzinger, Nowa pieśń dla Pana, dz. cyt., s. 38-39.

52 Jan Paweł II, Przekroczyć próg nadziei, Lublin 1994, s. 144.

53 Por. FR 29.

54 Por. J. Krucina, Komentarz do encykliki Jana Pawła II „Centesimus annus”, w: Jan Paweł II, Encyklika „Centesimus annus”, Wrocław 2000, s. 140.

${ }_{55}$ Jan Paweł II, Przemówienie do uczestników Kongresu Teologów Europy Środkowo-Wschodniej wygłoszone w Częstochowie (15 VIII 1991), dok. cyt., 7.

56 Por. K. Klauza, Od blasku prawdy, droga sumienia ku światłości wiecznej, w: Wokót encykliki „Veritatis splendor”, Częstochowa 1994, s. 161.
} 
To otwarcie na prawdę i jej poznanie możliwe są ostatecznie przez wiarę, która ma charakter wewnętrznego daru. Wiara pokazuje wyraźnie człowiekowi, w jakim kierunku chce go prowadzić Bóg i daje jego sumieniu pełną jasność. Prawda bowiem jest dostępna jedynie dzięki wierze. Dialog z Bogiem jest więc dialogiem prawdy w jej życiowym wymiarze, a jej poznanie wiąże się nierozerwalnie $z$ wiarą, która w ten sposób staje się fundamentalną postawą moralną. Chociaż wartości wiary nie da się wyjaśnić w szczególności potrzebami samej tylko ludzkiej moralności, to jednak właśnie wiara dostarcza możliwie najgłębszego jej uzasadnienia ${ }^{57}$.

Splendor Veritatis, Splendor Christi staje się na mocy tej logiki blaskiem rozsiewanym w życiu codziennym, poprzez słowo i świadectwo czynu, przez samego chrześcijanina - człowieka Chrystusowego ${ }^{58}$. Status świadka (tego, który daje świadectwo prawdzie) jest podstawowym statusem człowieka ${ }^{59}$-przypomina Jan Paweł II. To uprawnia nas do tego, że możemy o człowieku powiedzieć, że jest capax Dei, dlatego właśnie, że jest capax veri, to znaczy otwiera się na Boga przez otwarcie na prawdę ${ }^{60}$. Pragnienie prawdy jest tak głęboko zakorzenione $w$ sercu człowieka, że gdyby musiał się go wyrzec, prowadziłoby to do kryzysu egzystencjalnego ${ }^{61}$. I dlatego z wartości prawdy, która nie tylko do miłości wyzwala, ale także jest podstawą miłości, która jest zasadą i fundamentem wszelkiej sprawiedliwości oraz najcenniejszym skarbem w życiu ludzi i społeczeństw i na której wreszcie zasadza się całe życie moralne, zrezygnować nie można ${ }^{62}$. Żyć w prawdzie nigdy

\footnotetext{
57 Por. J. Nagórny, Teologia moralna jako eklezjalna nauka wiary w świetle „Veritatis splendor”, art. cyt., s. 181-182; J. Ratzinger, Prawda w teologii, dz. cyt., s. 63; Jan Paweł II, Przekroczyć próg nadziei, dz. cyt., s. 142.

58 A. Siemieniewski, Coraz bardziej istniejąc, upodabniamy się do Jego obrazu, art. cyt., s. 237.

59 Jan Paweł II, Przemówienie do uczestników Kongresu Teologów Europy Środkowo-Wschodniej (15 VIII 1991), dok. cyt., 7.

60 A. Szostek, Sanktuarium spotkania i dialogu, „Pastores” 1999, nr 4, s. 37.

61 FR 29.

62 Por. J. M. Lustiger, Bądźcie godni swego człowieczeństwa, Warszawa 1998, s. 112. 114; por. Jan Paweł II, Wolność jest łaska i nakazem. Audiencja generalna (10 VIII 1983), 4,
} 
nie było łatwo. Ale kto wie, czy dziś w okresie nasilonych przemian, napięć, sporów i przewartościowań, nie trzeba położyć szczególnego nacisku na ten podstawowy element i etap wychowania sumienia, bez którego wszelkie następne okażą się zbędne lub szkodliwe: uczciwość. Uczciwość najpierw w myśleniu, która polega na pokornym i odważnym szukaniu prawdy, przyjmowaniu jej i głoszeniu ${ }^{63}$. Prawdy tej się nie głosi i nie urzeczywistania inaczej jak tylko przez miłość; trzeba zawsze czynić prawdę w miłości ${ }^{64}$.

\section{Prawda jako granica wolności sumienia}

Wychowanie do życia w prawdzie łączy się w sposób istotny z kształtowaniem moralnego sumienia ${ }^{65}$. Wolność zawiera w sobie zawsze zależność od prawdy, co z całą wyrazistością przejawia się w sumieniu ${ }^{66}$. Prawdziwa wolność jest ściśle i organicznie związana z prawda: prawda stanowi korzeń wolności ${ }^{67}$. Zależność od prawdy określa granice właś-

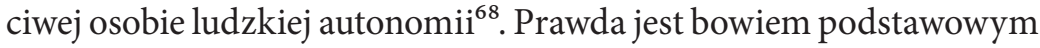
i niezbywalnym warunkiem transcendencji i wolności człowieka ${ }^{69}$. Jest ona przedmiotem transcendencji osoby i na tym polega istota ludzkiej racjonalności ${ }^{70}$.

Właściwa i zupełna funkcja sumienia polega na uzależnieniu czynu od prawdy. Niejednokrotnie ta właśnie prawda ogranicza ludzką samowolę i staje w poprzek niegodziwym zachciankom, od strony pozytywnej zaś jest najpewniejszą przewodniczką na drodze wiodącej

„L'Osservatore Romano” - wydanie polskie 1983, nr 7-8; J. Tischner, przedmowa do: J. M. Lustiger, Bądźcie godni swego człowieczeństwa, Warszawa 1998, s. 16-17.

63 A. Szostek, Pogadanki z etyki, Częstochowa 1998., s. 164.

${ }^{64}$ Por. Jan Paweł II, Przekroczyć próg nadziei, dz. cyt., s. 122.

65 Por. J. Augustyn, Wychowanie do czystości i celibatu kapłańskiego, dz. cyt., s. 45.

${ }^{66}$ Por. P. Góralczyk, Sumienie a prawda i wolność, art. cyt., s. 98.

67 Jan Paweł II, Przemówienie do uczestników Kongresu Teologów Europy Środkowo-Wschodniej (15 VIII 1991), dok. cyt., 7.

68 Por. Osoba i czyn oraz inne studia antropologiczne. Człowiek i moralność, t. 4, red. T. Styczeń, W. Chudy, Lublin 1994, s. 198.

69 Por. J. Kupczak, W stronę wolności, dz. cyt., s. 101; por. Osoba i czyn oraz inne studia antropologiczne, dz. cyt., s. 199.

70 Por. J. Marecki, Wyzwalajaca moc prawdy, art. cyt., s. 132. 
ku prawdziwej wolności ${ }^{71}$. To ograniczenie wolności jest w rzeczywistości gwarancją wyzwolenia, nobilitacją osobowości. W tym sensie sumienie chrześcijanina staje się realnie normą wolności. Wolność i prawda przynoszone są człowiekowi jako realna możliwość jego przyszłości. Realizacja zaś tej prawdy osiągniętej w wolności, choćby okupione to było ceną krzyża, jest już nagrodą oczywistą samą w sobie $^{72}$. Jedynie znosząc cierpliwie prawdę dojrzewamy od wewnątrz, stajemy się wolni od nas samych i wolni dla Boga ${ }^{73}$.

Człowiek jest wolny o tyle, o ile w swoich decyzjach, wyborach i w całym działaniu, kieruje się prawdą poznaną obiektywnie i bezstronnie ${ }^{74}$. Oderwanie wolności od obiektywnej prawdy uniemożliwia oparcie praw człowieka na solidnej bazie racjonalnej i stwarza sytuacje, w której w społeczeństwie może zapanować anarchiczna samowola jednostek albo zabójczy totalitaryzm władzy ${ }^{75}$. Beztreściowa, formalna tylko wolność, indywidualistyczna, która urasta do najwyższego celu, niweluje prędzej czy później samą siebie, zmierza do anarchii i zamyka człowieka w egoizmie ${ }^{76}$.

Człowiek wolny działa mocą sumienia, a więc mocą własną oraz mocą Transcendencji ${ }^{77}$. Przeto każdy ma obowiązek, a stąd też i prawo szukania $w$ dziedzinie religijnej, aby przez użycie właściwych środków urobit sobie roztropnie stuszny i prawdziwy sad sumienia ${ }^{78}$. Sumienie, aby umiało poprawnie wskazywać granicę dobra i zła, musi

\footnotetext{
71 Por. J. Ratzinger, Nowa pieśń dla Pana, dz. cyt., s. 257; W. Gubała, Wychowanie moralne młodzieży, art. cyt., s. 209.

72 Por. S. Rosik, Wezwania i wybory moralne, dz. cyt., s. 253.

73 Por. J. Ratzinger, Nowa pieśń dla Pana, dz. cyt., s. 257.

74 Por. Jan Paweł II, Przemówienie do uczestników Kongresu Teologów Europy Środkowo-Wschodniej (15 VIII 1991), dok. cyt., 7; W. Gubała, Wychowanie moralne młodzieży, art. cyt., s. 209; R. Rybicki, Wprowadzenie do pedagogiki chrześcijańskiej, dz. cyt., s. 34 .

${ }^{75}$ EV 96.

76 Por. Jan Paweł II, Ewangelia jest droga pokoju, sprawiedliwości i wolności, dok. cyt., 6; J. Krucina, Komentarz do encykliki Jana Pawła II „Centesimus annus”, art. cyt., s. 137.

77 Por. S. Grygiel, Kimże jest człowiek?, Kielce 1995, s. 237.

${ }^{78}$ DWR 3
} 
opierać się na prawdzie ${ }^{79}$. Jan Paweł II nie pozostawia w tym względzie cienia wątpliwości, stwierdzając, że nie można nawet wkroczyć na droge prowadzaca do dojrzałości sumienia, jeżeli duch nie jest wolny od śmiertelnej choroby (...) - od obojętności wobec prawdy ${ }^{80}$. Tylko wolność podporządkowana Prawdzie prowadzi osobę ludzką ku jej autentycznemu dobru. Dobrem osoby jest istnienie w Prawdzie i czynienie Prawdy. Nieprawe jest więc takie sumienie, które kieruje się innym kryterium niż prawda. Prymat sumienia jest zakorzeniony $\mathrm{w}$ prymacie prawdy i przez nią zagwarantowany ${ }^{81}$.

$\mathrm{Na}$ fakt, że tych dwóch ściśle sprzężonych ze sobą rzeczywistości (wolności i prawdy) w żaden sposób nie wolno rozdzielać, wskazuje radykalny rozdział przeprowadzony między prawdą a wolnością i przyznanie pierwszeństwa wolności przed prawdą. Następstwem owego oddzielenia wolności od prawdy, także woli od rozumu, prawdy od dobra, wiary od moralności czy wolności od miłości, jest przyjmowanie współczesnych trendów myślowych (np. totalitaryzmu, liberalizmu, sceptycyzmu, ateizmu, scjentyzmu i in.) ${ }^{82}$. Wymienione ideologie powodują coraz silniejsze rozchwianie osobowości człowieka, relatywizację i subiektywizację jego życia (postępowania) oraz poznania. Wspólnym ich mianownikiem jest walka z cywilizacją łacińską, chrześcijaństwem będącym syntezą wielkich kultur: Biblii i antyku grecko-rzymskiego. Nurty te, choć różnorodne, mają jedną cechę wspólną: osłabiają lub wręcz negują zależność wolności

\footnotetext{
79 Por. K. Janiak, Ku dojrzałej wolności przez wychowanie sumienia, „Wrocławski Przegląd Teologiczny", 1997, nr 2, s. 98.

80 Jan Paweł II, Kościół jest miejscem, w którym sumienie ludzkie wzrasta i dojrzewa, dok. cyt., 1.

81 Por. DWR 7; K. Janiak, Ku dojrzałej wolności przez wychowanie sumienia, art. cyt., s. 99; L. Melina, Sumienie - wolność - Magisterium, art. cyt., s. 102.

${ }^{82}$ Por. I. Dec, Blask prawdy w wolności i wolności w prawdzie, w: W prawdzie ku wolności. W kręgu encykliki „Veritatis splendor”, dz. cyt., s. 114-115; J. Nagórny, Teologia moralna jako eklezjalna nauka wiary w świetle „Veritatis splendor”, art. cyt., s. 178; A. Szostek, Rola Kościoła w kształtowaniu dojrzałego sumienia, „W drodze” 1984, nr 2, s. 61; J. Tarnowski, Budzenie i rozwój sumienia, „Warszawskie Studia Teologiczne" 1992, nr 5, s. 210; A. Rynio, Szkoła w wychowaniu moralnym, w: Pedagogika katolicka, red. A. Rynio, Stalowa Wola 1999, s. 359.
} 
od prawdy. W konsekwencji uderzają w samą istotę osoby ludzkiej, gdyż brak jest w tej nowej wizji osoby podstawowego odniesienia do Absolutu-Prawdy; co z taką mocą podkreśla chrześcijństwo ${ }^{83}$.

Problem kształtowania w człowieku prawidłowego sumienia stał się dzisiaj tragicznym problemem społecznym - tragicznym, ponieważ zbyt często nie dostrzeganym. Obserwujemy na wielką skalę niedorozwój sumienia ${ }^{84}$. W obliczu obserwowanych we współczesnym świecie zjawisk mogą nie dziwić opinie tych, którzy mówiąc o kryzysie kultury i cywilizacji, wskazują, jako na pochodną jednego z najgłębszych kryzysów człowieka, na kryzys moralny - kryzys sumienia oraz na kryzys prawdy ${ }^{85}$. J. Ratzinger w tej sytuacji nie waha się postawić nawet tezy, że wielką chorobą naszych czasów jest ubóstwo prawdy, którą zewsząd wypiera sukces i skuteczność ${ }^{86}$.

Niestety, współcześnie wielu ludziom, aby żyć, nie jest potrzebna prawda, lecz złudzenie; człowiek woli słodkie złudzenia niż gorzkie prawdy ${ }^{87}$. W konsekwencji czasami dochodzi do tego, że ludzie deklarujacy się jako chrześcijanie zapominaja o co w ogóle chodzi $w$ chrześcijaństwie i zaczynaja akceptować substytuty, które można wyprodukować niższym kosztem, i które zdaja się spetniać te same funkcje, co oryginat ${ }^{88}$. Świadomość wyboru między dobrami partykularnymi, albo między dobrem a złem, jest tu o tyle myląca, że jesteśmy skłonni dopatrywać się w niej istoty wolności, podczas gdy

\footnotetext{
83 Por. K. Kłosowski, S. Czalej, Analogiczne poznanie Boga w ujęciu biskupa profesora Bohdana Bejze, „Studia Gdańskie” 1999, nr 12, s. 21-22; A. Szostek, Encyklika o rozeznawaniu duchów, w: Wokót encykliki „Veritatis splendor”, Częstochowa 1994, s. 29; K. Kłosowski, S. Czalej, Analogiczne poznanie Boga w ujęciu biskupa profesora Bohdana Bejze, art. cyt., s. 21-22.

${ }^{84}$ Por. J. Tischner, Jak $\dot{z} y c ́$ ?, dz. cyt., s. 25.

85 Por. J. Bagrowicz, Wychowanie sumienia u podstaw wychowania integralnego, art. cyt., s. 81; por. M. Pokrywka, Rola Duch Świętego w kształtowaniu dojrzałego sumienia, art. cyt., s. 194.

86 Por. J. Ratzinger, Nowa pieśń dla Pana, dz. cyt., s. 259.

87 Por. W. Kawecki, Jubileusz chrześcijaństwa czasem odnowienia wiary i świadectwa, „Homo Dei” 1999, nr 4, s. 90.

88 W. K. Kilpatrick, Psychologiczne uwiedzenie, Poznań 1997, s. 115.
} 
jest ona tylko refleksem wolności ontologicznej, a nie całą, ani nawet nie zawsze właściwą jej realizacją ${ }^{89}$.

Wolność w tym kontekście pojmowana jest jako wolność sumienia od prawa - sumienie byłoby wolne, $\mathrm{w}$ takiej mierze $\mathrm{w}$ jakiej zachowałoby dla siebie ostateczny sąd w stosunku do Magisterium ${ }^{90}$. Zapomina się, że to poddanie sumienia wyższej, wyrażonej przez prawo moralne, normie nie znosi wcale w człowieku ani wolności psychologicznej, ani wolności moralnej. Przeciwnie, jeżeli Stwórca daje swemu stworzeniu prawo, to osadza je przede wszystkim w sytuacji wyboru, tzn. w wolności. Stąd Kościół, kiedy naucza i zobowiązuje wiernych do przestrzegania głoszonej nauki, nie narusza wolności sumień, nie tylko dlatego, że wolność sumienia nie jest nigdy wolnościa od prawdy, ale zawsze i wyłącznie w prawdzie, lecz także dlatego, iz Magisterium nie wprowadza do chrześcijańskiego sumienia prawd mu obcych, a tylko objawia prawdy, które sumienie powinno już znać i rozwijać je, wychodzac od pierwotnego aktu wiary ${ }^{91}$. Ewangelia i Urząd Nauczycielski to nie są dwie odrębne wielkości: urząd pozostaje w służbie słowa Bożego ${ }^{92}$.

Sumienie wraz z ludzką wolnością stanowi o kształcie naszego człowieczeństwa, o pełnym przeżywaniu jego sensowności i celowości ${ }^{93}$. Człowiek jest wolny nie pomimo sumienia, lecz dzięki sumieniu, poprzez sumienie. Sumienie jest warunkiem sine qua non ludzkiej wolności, wolności - rzecz oczywista - nie rozumianej jednak jako zależnej wyłącznie od samej siebie, od swego wolnego samookreślenia się bez dodatkowych determinacji ${ }^{94}$. Działać zgodnie z sumieniem znaczy być na tyle silnym, by nie dać się zniewolić ani uczuciom, ani

\footnotetext{
89 Por. J. Majka, Chrześcijańska myśl społeczna, dz. cyt., s. 122-123.

90 Por. L. Melina, Sumienie - wolność - Magisterium, art. cyt., s. 94.

91 VS 64.

92 Por. J. Nagórny, Teologia moralna jako eklezjalna nauka wiary w świetle „Veritatis splendor", art. cyt., s. 189.

93 Por. J. Augustyn, Pustka egzystencjalna a leczenie zranionego sumienia, art. cyt., s. 45 .

94 Por. T. Styczeń, Wprowadzenie do etyki, dz. cyt., s. 99; L. Melina, Sumienie wolność - Magisterium, art. cyt., s. 97.
} 
ideologiom, do których z całą pewnością zaliczyć można współczesne tendencje zmierzające do ateizacji i autonomizacji sumienia, w konsekwencji zaś do jego redukcji aż do absurdu ${ }^{95}$.

\section{Sumienie: nie creator lecz lector prawdy}

Wolność nie ogranicza ludzkiego działania pod warunkiem, że pozostaje ona w symbiozie z prawdą i dobrem ${ }^{96}$. Dojrzale wolnym jest ten, kto trafnie dobro spostrzegł i trwale się za nim opowiedział. Stąd dobrze wybrane dobro nie tylko nie ogranicza wolnej woli, ale z niej wypływa i samą wolność pogłębia ${ }^{97}$. Choć każdy wybór przez nas dokonywany jest jakimś przejawem wolności, to jednak nie każdy czyni nas doskonale wolnymi, nie każdy nas rzeczywiście wyzwala. Mogą i bywają takie wybory, które zbliżają nas do zniewolenia, stanowią krok do poddania nas determinacji ${ }^{98}$. Człowiek pytając o to, jak być, ,dobrze wolnym”, pyta po prostu o to, jak być „wolnym w prawdzie". Oto istota fenomenu, który nazywamy ludzkim sumieniem, oto również powód, dla którego nie można mówić o splendorze wolności w oderwaniu od splendoru prawdy ${ }^{99}$.

W instrukcji Kongregacji Nauki Wiary Libertatis constientia z 1986 roku czytamy: Wolność nie daje nam prawa do mówienia i czynienia wszystkiego. Jest ona uwarunkowana prawda i musi sie liczyć $z$ dobrem innych ${ }^{100}$. Z tej relacji pomiędzy sumieniem i prawdą wynikają - zdaniem T. Stycznia - dwie wizje roli sumienia: sumienie jako lector i sumienie jako creator $^{101}$. Wyznaczają one dwie diametralnie różne wizje moralności. Wobec powyższego nasuwa się pytanie: która $\mathrm{z}$ dwu relacji pomiędzy wolnością i naturą człowieka

\footnotetext{
95 Por. J. M. Lustiger, Bądźcie godni swego człowieczeństwa, dz. cyt., s. 76; J. Bagrowicz, Wychowanie sumienia u podstaw wychowania integralnego, art. cyt., s. 85. 96 Por. K. Janiak, Ku dojrzałej wolności przez wychowanie sumienia, art. cyt., s. 101.

97 Por. A. Szostek, Sanktuarium spotkania i dialogu, art. cyt., s. 29.

98 Por. J. Majka, Chrześcijańska myśl społeczna, dz. cyt., s. 123.

99 J. Marecki, T. Styczeń, „Veritatis splendor” - encyklika o wolności, art. cyt., s. 208-209.

${ }^{100}$ LC 9.

101 T. Styczeń, Osoba ludzka: wolność przeciw naturze?, „Ethos” 1991, nr 15-16, s. 21.
} 
odpowiada prawdzie? Odpowiedź jest następująca: sumienie jest lektorem prawdy o człowieku, a nie kreatorem tej prawdy ${ }^{102}$. Zadaniem sumienia nie jest zatem tworzenie nowych norm ogólnych, ale ich aplikacja w konkretnych przypadkach ${ }^{103}$. Ogólne wymagania Boże dzięki sumieniu zostają zsubiektywizowane, ukonkretnione, zaaplikowane do osobistej, indywidualnej sytuacji konkretnego podmiotu. Realizując istotne zadania życiowe, człowiek ma obowiązek osobiście je rozpoznać w konkretnych sytuacjach, ustalić należyte rozwiązania, nie popadając jednak przy tym w błędne stanowisko skrajnej etyki sytuacyjnej, etycznego egzystencjalizmu, aktualizmu czy indywidualizmu ${ }^{104}$. Istota sumienia wyraża sie w znanym każdemu wewnętrznym głosie wzywającym człowieka, by rozpoznaną i uznaną prawdę uczynił kryterium swego postępowania. Sumienie ma odczytywać to, co Bóg chce, a nie tworzyć wygodne dla siebie pseudonormy. Rozum bowiem o tyle zasługuje na swą nazwę, o ile zdolny jest poznać prawdę, nie zaś ją konstruować. Nieuzasadniona jest więc taka wizja sumienia, która przypisuje mu prawo do arbitralnego określania treści prawdy wiążącej człowieka ${ }^{105}$.

Etyka sporej części ludzi młodych mieści się jakby pośrodku miedzy legalizmem a sytuacjonizmem, wolność jest absolutnym prawem jednostki, a sumienie czysto subiektywną i całkowicie autonomiczną instancją normotwórczą ${ }^{106}$. W ten sposób w mentalności współczesnego człowieka chrześcijańską zasadę: postępować wbrew sumieniu jest zawsze grzechem, zastąpiła inna, całkowicie odmienna: grzeszy się jedynie wówczas, kiedy postępuje się wbrew (subiektywistycznie

\footnotetext{
${ }^{102}$ Por. T. Styczeń, Dlaczego encyklika o blasku prawdy?, „Niedziela” 1993, nr 45, s. 1 i 19.

${ }_{103}$ Por. K. Janiak, Ku dojrzałej wolności przez wychowanie sumienia, art. cyt., s. 98. ${ }^{104}$ Por. S. Rosik, Formowanie sumienia chrześcijańskiego w relacji do normy obiektywnej, art. cyt., s. 19; tenże, Wezwania i wybory moralne, dz. cyt., s. 242.

105 Por. K. Klauza, Od blasku prawdy, drogą sumienia ku światłości wiecznej, art. cyt., s. 162; T. Styczeń, Dlaczego encyklika o blasku prawdy?, art. cyt., s. 1 i 19; A. Szostek, Encyklika o rozeznawaniu duchów, art. cyt., s. 45.

${ }_{106}$ Por. J. Mariański, Kondycja moralna społeczeństwa polskiego: hipotezy wstępne, „Społeczeństwo” 2000, nr 1, s. 177.
} 
pojętemu) sumieniu ${ }^{107}$. Sumienie w subiektywizmie staje się instancją nieomylną, staje się kreatywne w odniesieniu do prawdy i nie jest jej podporządkowane. W taki sposób pojęta autonomia człowieka wolna jest od wewnętrznego powiązania jego sumienia z prawdą i prawem moralnym. Ostatecznie przeciwstawiana autorytetowi tradycji wolność sądu, z racji jego samodzielności i indywidualności, liczy się bardziej, aniżeli sama prawda. Jednak wbrew wszelkim koncepcjom autonomistycznym i kreatywistycznym sumienie jest świadkiem prawdy, która wyprzedza je i przewyższa, na którą winno się otwierać w pokornym jej poszukiwaniu, tak by odbijać w sobie blask poznanej i uznanej prawdy ${ }^{108}$.

\section{Streszczenie:}

Posłuszeństwo wobec sumienia domaga się posłuszeństwa wobec prawdy, a ta musi być stawiana wyżej niż wszelka instancja społeczna i wszelkie indywidualne upodobania, które nie mogą być społecznie korzystniejsze z kolektywną ugodą, z roszczeniami władzy politycznej czy społecznej. Niebezpieczeństwo, że zrezygnujemy z roszczenia do prawdy, pozornie z szacunku do innego roszczenia, pozornie z powodu pokory, w rzeczywistości znaczy, że wybieramy własną wygodę, że nie przyjmujemy już wielkości chrześcijaństwa, że ostatecznie deformujemy wiarę. Nikt nie może rozpoznać prawdy za kogoś. Wolność jest istotnym sposobem działania człowieka. Dotyczy to zarówno poznania prawdy, której nie jesteśmy w stanie jako ludzie, przyjąć pod przymusem, jak i dążenia do dobra. Bóg uznał dar wolności za tak cenny, że nie wahał się zaryzykować możliwości ludzkiego błędu nawet w dochodzeniu do prawdy. Człowiek nie może stać się uczestnikiem prawdy w inny sposób, jak tylko przez to, że skłoni ku niej swój umysł, że ją niejako ujrzy i dojdzie do wewnętrznego przekonania, iż nie może jej nie przyjąć.

107 L. Melina, Drogocenne i kruche sumienie, art. cyt., s. 102.

108 Por. L. Melina, Drogocenne i kruche sumienie, art. cyt., s. 103. 


\section{Summary:}

Following the dictates of conscience is immanently connected with observing the dictates of truth. Truth has to be given priority over any social and individual institutions and choices. It cannot be subjected to any claims of political and social powers. The danger of giving up the paramount respect for truth involves the risk that we shall abandon seeking the truth apparently on account of respecting some other claim or due to humility means, in reality, that we give preference to our own comfort. It is equivalent to rejecting the essential importance of Christianity and eventually lead to deformation of faith.

No one can recognize truth for someone else. It refers to the recognition of truth which, being humans, we are not able to identify forcibly. It also refers to our pursuit of good. God treated the gift of freedom as so unique and precious that $\mathrm{He}$ did not hesitate to permit people to commit errors even in the process of seeking truth. Man can achieve truth only by an effort of mental comprehension. This means he will have to, in a way, visualize it and reach the internal conviction that he cannot reject it.

Słowa kluczowe: sumienie, wolność, prawda, wychowanie chrześcijańskie, moralność, etyka chrześcijańska, kształtowanie sumienia, wychowanie do prawdy, formacja moralna.

Key words: conscience, freedom, truth, christian upbringing, morality, christian ethics, formation of conscience, upbringing in the spirit of truth, moral formation.

\section{Biogram:}

Ks. Marek Filipczuk - kapłan diecezji warszawsko - praskiej, teolog moralista, doktor nauk teologicznych w zakresie teologii moralnej, wykładowca teologii moralnej na Wydziale Teologicznym Uniwersytetu Kardynała Stefana Wyszyńskiego w Warszawie.

\section{Bibliografia:}

Bagrowicz J., Wychowanie sumienia u podstaw wychowania integralnego, w: Edukacja wobec dylematów moralnych współczesności, red. F. Adamski,

A. M. de Tchorzewski, Kraków 1999, s. 81-101.

Benedykt XVI, Deus caritas est, Watykan 2005. 
Dziewiecki M., Człowiek w obliczu sumienia, w: Sumienie. Głos Boga w duszy. Wybór tekstów, opr. M. Czekański, Kraków 2002, s. 160-168.

Franciszek, Modlitwa na Anioł Pański 6 grudnia 2015, http://papiez.wiara. pl/doc/2862422.Franciszek-o-potrzebie-ciaglego-nawrocenia.

Góralczyk P., Sumienie a prawda i wolność, „Communio” 2000, nr 1, s. 95-107.

Guardini R., Zjawisko sumienia, „Znak” 1996, nr 7, s. 13-28.

Jan Paweł II, Chrystus jest cała prawda człowieka (31 VIII 1983), 3, „L'Osservatore Romano” - wydanie polskie 1983, nr 7-8.

Jan Paweł II, Czas próby polskich sumień trwa. Homilia wygłoszona $22 \mathrm{~V}$ 1995 r. w Skoczowie, 3, „Więź” 1995, nr 7.

Jan Paweł II, Odnowa człowieka i społeczeństwa dokonuje się za sprawa odnowy sumień (14 II 1998), 2, „L'Osservatore Romano” - wydanie polskie 1998, nr 3.

Jan Paweł II, Orędzie na Światowy Dzień Pokoju (8 XII 1980), Chcesz służyć sprawie pokoju - szanuj wolność, 11, „L'Osservatore Romano” - wydanie polskie 1980.

Jan Paweł II, Podstawa etyki chrześcijańskiej: związek pomiędzy prawda i wolnościa (13 VI 1983), 1, „L'Osservatore Romano” - wydanie polskie 1983, nr 7-8.

Jan Paweł II, Przekroczyć próg nadziei, Lublin 1994.

Janiak K., Ku dojrzałej wolności przez wychowanie sumienia, „Wrocławski Przegląd Teologiczny”, 1997, nr 2, s. 97-104.

Kawecki W., Jubileusz chrześcijaństwa czasem odnowienia wiary i świadectwa, „Homo Dei” 1999, nr 4, s. 85-96.

Kawecki W., Spowiedź a kształtowanie sumienia, „Homo Dei” 2001, nr 1, s. 35-46.

Klauza K., Od blasku prawdy, droga sumienia ku światłości wiecznej, w: Wokół encykliki „Veritatis splendor”, Częstochowa 1994, s. 155-170.

Krąpiec M. A., Człowiek i prawo naturalne, Lublin 1986.

Krucina J., Komentarz do encykliki Jana Pawła II „Centesimus annus”, w: Jan Paweł II, Encyklika „Centesimus annus”, Wrocław 2000.

Lustiger J. M., Bądźcie godni swego człowieczeństwa, Warszawa 1998.

Mariański J., Kondycja moralna społeczeństwa polskiego: hipotezy wstępne, „Społeczeństwo” 2000, nr 1, s. 163-185.

Melina L., Sumienie - wolność - Magisterium, „Ethos” 1991, nr. 3-4, s. 94-112.

Nagórny J., Teologia moralna jako eklezjalna nauka wiary $w$ świetle „Veritatis splendor”, w: W prawdzie ku wolności. W kręgu encykliki „Veritatis splendor", red. E. Janiak, Wrocław 1994, s. 177-197. 
Nagórny J., Z Chrystusem w Trzecie Tysiaclecie, w: Wyzwania moralne przełomu tysiącleci, red. J. Nagórny, A. Derdziuk, Lublin 1999, s. 163-175.

Nowak M., „Sumienie” jako szczególne miejsce doświadczania i urzeczywistniania swojego człowieczeństwa, w: Sumienie. Głos Boga w duszy. Wybór tekstów, opr. M. Czekański, Kraków 2002, s. 180-209.

Pokrywka M., Rola Duch Świętego w kształtowaniu dojrzałego sumienia, w: Sumienie. Głos Boga w duszy. Wybór tekstów, opr. M. Czekański, Kraków 2002, s. 191-206.

Ratzinger J., Czas przemian w Europie, Kraków 2001.

Ratzinger J., Nowa pieśń dla Pana, Kraków 1999.

Ratzinger J., Prawda w teologii, Kraków 2001.

Ratzinger J., Prawda, wartości, władza, Kraków 1999.

Rosik S., Sumienie między wolnością a prawdą, w: Człowiek sumienie, wartości, red. J. Nagórny, A. Derdziuk, Lublin 1997, s. 103-118.

Schnackenburg R., Nauka moralna Nowego Testamentu, Warszawa 1983.

Styczeń T., Sumienie a Europa czyli Gdyby Ojciec Święty zaprosił Arystotelesa na Synod Biskupów Europy 1991, „Ethos” 1991, nr 15-16, s. 156-170.

Szostek A., Encyklika o rozeznawaniu duchów, w: Wokót encykliki „Veritatis splendor", Częstochowa 1994, s. 19-51.

Szostek A., Rola Kościoła w kształtowaniu dojrzałego sumienia, „W drodze” 1984, nr 2, s. 54-64.

Tarnowski J., Budzenie i rozwój sumienia, „Warszawskie Studia Teologiczne” 1992, nr 5, s. 201-216.

Tischner J, Przedmowa, w: J. M. Lustiger, Bądźcie godni swego człowieczeństwa, Warszawa 1998, s. 16-17. 